\title{
PERFORMANCE OF THE ORIGINAL WORKSTATION FOR AEROSOL TESTS UNDER CONTROLLED CONDITIONS
}

\author{
Kleymenov DA ${ }^{1 凶}$, Verdiev $\mathrm{BI}^{1}$, Enenko $A A^{2}$, Gushchin $\mathrm{VA}^{1,3,4}$, Tkachuk $\mathrm{AP}^{1}$ \\ Laboratory of Translational Biomedicine, \\ Gamaleya Research Institute of Epidemiology and Microbiology, Moscow \\ ZZAO Laminar Systems, Miass, Chelyabinsk oblast \\ ${ }^{3}$ Laboratory of Population Variability Mechanisms in Pathogenic Microorganisms, \\ Gamaleya Research Institute of Epidemiology and Microbiology, Moscow \\ ${ }^{4}$ Department of Virology, Faculty of Biology, Lomonosov Moscow State University, Moscow
}

Air quality monitoring is essential when it comes to protecting the urban population, especially that of big metropolises, from biohazards including biopathogens (BPs). This process is aided by different samplers and analyzers of aerosol pollutants, filters and disinfection systems. Their performance is tested using experimental aerosol formulations with a predetermined composition. Unfortunately, the majority of such systems available in Russia are only able to process a few hundred liters of air per time unit, which is too little. Big aerosol chambers $\left(10\right.$ to $\left.20 \mathrm{~m}^{3}\right)$ are very expensive and may not fit into a lab, necessitating an extensive overhaul. In this work we present a workstation for the detection of BP markers under controlled conditions based on the microbiological safety box MSB-III-Laminar-C-1.5 (380.150.01) that was originally designed to test the performance of samplers and analyzers of experimental aerosol formulations. Our workstation can handle the majority of BSL-1-2 BPs and, given the chamber volume that satisfies the requirements of aerosol experiments $\left(>4 \mathrm{~m}^{3}\right)$, can be installed in a lab with an area of $>10 \mathrm{~m}^{2}$.

Keywords: infection, aerosol, aerosol sampling, aerosol chamber

Funding: this work was supported by the Ministry of Health of the Russian Federation as part of the project The National System for Chemical and Biological Security of the Russian Federation (2015-2020) and by the Ministry of Education and Science as part of the project RFMEFI60117X0018.

$\triangle$ Correspondence should be addressed: Denis A. Kleymenov

Gamalei 18, Moscow, 123098; 10000let@rambler.ru, denis.a.kleymenov@gamaleya.org

Received: 06.08.2018 Accepted: 31.08.2018

DOI: $10.24075 /$ brsmu.2018.053

\section{ОПЫТ ИСПОЛЬЗОВАНИЯ АНАЛИТИЧЕСКОГО СТЕНДА ДЛЯ ПРОВЕДЕНИЯ АЭРОЗОЛЬНЫХ ИСПЫТАНИЙ В КОНТРОЛИРУЕМЫХ УСЛОВИЯХ}

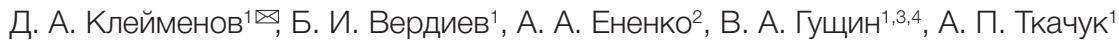 \\ Л Лаборатория трансляционной биомедицины, \\ Национальный исследовательский центр эпидемиологии и микробиологии имени Н. Ф. Гамалеи Минздрава России, Москва \\ 2 ЗАО Ламинарные системы, Миасс, Челябинская обл. \\ з Лаборатория механизмов популяционной изменчивости патогенных микроорганизмов, \\ Национальный исследовательский центр эпидемиологии и микробиологии имени Н. Ф. Гамалеи Минздрава России, Москва \\ ${ }^{4}$ Кафредра вирусологии, биологический факультет, Московский государственный университет имени М. В. Ломоносова, Москва
}

\begin{abstract}
Для обеспечения безопасности проживающих в условиях города людей необходимо контролировать воздушную среду населенных пунктов и прежде всего мегаполисов на наличие патогенных биологических агентов (ПБА). Разрабатываются различные системы контроля биологического состава воздушной среды (сбор и анализ аэрозоля) и ее очистки (фильтрация, дезинфекция). Возможность экспериментального создания аэрозолей заданного состава является необходимым условием разработки любых подобных устройств. Рабочий объем большинства установок для работы с аэрозолями, имеющихся в России, достигает нескольких сотен литров, что недостаточно. Специальные аэрозольные камеры с большим рабочим объемом (10-20 м³) характеризуются высокой стоимостью и требуют проведения капитального строительства/реконструкции помещений для их установки. В настоящей работе представлен аналитический стенд для индикации маркеров ПБА в контролируемых условиях, разработанный на основе специального варианта бокса БМБ-ІІІ-«Ламинар-С»-1,5 (380.150.01), главным назначением которого является проведение тестов и испытаний приборов для сбора и/или анализа аэрозолей модельных биопатогенов. Устройство предназначено для проведения исследований начального и среднего уровня с большинством ПБА III группы патогенности внутри отдельной лаборатории. Внешние размеры позволяют устанавливать его в помещениях площадью от 10 м² при достаточном внутреннем объеме камеры для проведения испытаний (более 4 м³).
\end{abstract}

Ключевые слова: инфекционные заболевания, аэрозольные инфекции, сбор аэрозоля, аэрозольный стенд

Финансирование: статья подготовлена при поддержке Министерства здравоохранения Российской Федерации в рамках программы «Национальная система химической и биологической безопасности 2015-2020" и Министерства образования и науки РФ в рамках проекта RFMEFI60117X0018.

Для корреспонденции: Денис Александрович Клейменов

ул. Гамалеи, д. 18, г. Москва, 123098; 10000let@rambler.ru, denis.a.kleymenov@gamaleya.org

Статья получена: 06.08.2018 Статья принята к печати: 31.08.2018

DOI: $10.24075 /$ vrgmu.2018.053

In the modern world, air quality monitoring is becoming increasingly important. The evolution of biotechnologies has largely contributed to the natural diversity of biopathogens: genetically engineered microbial strains used in the pharmaceutical industry have turned into an additional source of environmental contamination [1]. Urban areas and agroindustrial zones provide a favorable environment for bacteria and viruses to thrive. Microorganisms settle in public places (clinics, maternity hospitals, metro systems) and utility networks (vent shafts, water supply systems, sewage networks). Some colonize animals and conquer their natural habitat. High density of the urban population, as well as its mobility, prepare 
the ground for the spread of airborne infectious aerosols [2]. In addition, bioterrorism still poses a serious threat [3, 4].

Fortunately, we have an extensive arsenal of tools for monitoring air contamination at our disposal capable of sampling aerosol particles, estimating their concentration and size, and identifying biopathogens contained in the sample. Obviously, adaptation of these devices to a specific task and improvement of their performance are impossible without proper testing involving the use of experimental aerosol formulations that model the behavior of the actual particulate matter. In an enclosed indoor aerosol test chamber, protection from hazardous bioaerosols can be ensured by state-of-the-art high-performance filters [5, 6].

Among the most important parameters the chamber has to meet are sufficient space to accommodate the equipment; easy access inside; reasonable dimensions compatible with the size of the room it will be installed in; the inbuilt system of incoming and exiting air filtration; even distribution of aerosol particles throughout the chamber volume; simplicity of cleaning and decontamination procedures. Modern class III biological safety cabinets (BSC-III) meet the majority of these requirements but one for the inner volume of the chamber [6].

\section{Design of the experiment}

Our bioaerosol test chamber devised for the detection of biopathogens in the controlled environment is a modernized version of the BSC-III Laminar-C-1.5 (380.150.01) designed to test samplers and analyzers of model bioaerosols.

A prototype of an aerosol sampler with liquid phase recirculation and preconcentration of particles was developed at the National Research Nuclear University MEPhl. The sampler can operate at a volumetric air flow of $4,000 \mathrm{l} / \mathrm{min}$ collecting particles of $>0.5 \mu \mathrm{m}$ in size. Its performance was compared to that of the SASS 4000/2300 aerosol concentration device with a cyclone air sampler (Research International Inc.; USA).

The main stages of chamber development and testing procedures are described below.

\section{Preparation}

\section{Equipment}

1.1. Chamber for the detection of hazardous bioaerosols in the controlled environment

BSC-III Laminar-C-1.5 (380.150.01) by ZAO Laminar Systems, Russia, is a class III biological safety enclosure (GOST R EN 12469-2010) with chamber dimensions of $1.5 \times 1.5 \times 1.9 \mathrm{~m}$ (Fig. 1). Before entering the chamber, the continuously supplied air passes through a high-efficiency class $\mathrm{H}$-14 inlet HEPA filter. The filter maintains a clean environment in the chamber corresponding to ISO class 5 of air cleanliness for $0.5 \mu \mathrm{m}$ particles (GOST 14644-1-2002). The air exits through a cascade of 2 consecutive class $\mathrm{H} 14$ exhaust HEPA filters. In the chamber, the negative pressure of at least $250 \mathrm{~Pa}$ (relative to the outside pressure) is created by exhaust fans, forcing the air to circulate in the chamber. The maximum air flow rate through the chamber is $800 \mathrm{~m}^{3} / \mathrm{h}$ but it can be reduced or terminated by adjusting the rotation speed of the exhaust fans and the position of a gate valve that changes the aerodynamic drag in the inlet air duct. The air containing aerosol particles generated in the chamber goes through a cascade of exhaust filters for decontamination and exits into the room where the workstation is installed. The negative pressure of $250 \mathrm{~Pa}$ maintained in the chamber minimizes the risk of aerosol leakage, which depends solely on the efficiency of HEPA filters cascade. This chamber is not equipped with separate air pipes for the aerosolcontaminated air, so the exiting air just travels straight into the first exhaust HEPA filter.

The equipment that needs to be tested is loaded into the chamber through a full-sized leak-tight door. The biaxial hinge mechanism and 4 handles allow the glass surface of the door to fit tightly against the door seal.

Inside the chamber, the environment is controlled by the monitoring equipment connected to a feedthrough panel. Another panel has all necessary airpipe fittings and electrical connectors to connect diagnostic and measuring equipment to the computer.

The operating mode is selected using a control sensor panel. The system can automatically maintain a preset air flow rate and negative pressure in the chamber and signal any abnormal situation or equipment failure. It also reports clogged HEPA- and prefilters and adjusts the fan speed and the position of the gate valve to compensate for a change in their aerodynamic drag.

Disinfection is performed according to standard protocols considering the specifics of the conducted tests. The chamber is equipped with a pair of UV lamps for primary disinfection. Terminal decontamination can be performed using formaldehyde or hydrogen peroxide vapor phases. The equipment required for decontamination can be plugged into 38-mm feedthroughs.

\subsection{Aerosol sampling device (National Research Nuclear University MEPhl; Russia)}

The aerosol sampler used for our tests consists of a virtual impactor connected to a cyclone by an air pipe (Fig. 2). The device exploits the idea of two-stage particle concentration, allowing to achieve high volumetric air flow rates of up to $4,000 \mathrm{l} / \mathrm{min}$. First, air is sucked into the nozzle of the virtual impactor where captured particles are concentrated. Then the air containing concentrated particles exits the impactor at $300 \mathrm{l} / \mathrm{min}$ and enters the cyclone collector where the captured particles precipitate in the sorption liquid circulating in the cyclone. The longer the circulation time, the higher the concentration of the incoming particles in the liquid phase. The volume of the released liquid sample is $7-8 \mathrm{ml}$.

\subsection{Air sampling device SASS 4000/2300 (Research International Inc.; USA)}

The air sampler SASS 4000/2300 utilizes a similar principle of action. In the first stage, the air flows into the impactor nozzle at $3,600 \mathrm{l} / \mathrm{min}$. In the second stage, the cyclone collector ensures the flow rate of $325 \mathrm{l} / \mathrm{min}$ and releases $4-5 \mathrm{ml}$ of the liquid sample.

\subsection{Portable aerosol particle counter SOLAIR 3100 (Lighthouse Worldwide Solutions; USA)}

This device is used to test the integrity of inlet and exhaust HEPA filters. In our experiment, we took measurements using 6 particle channels: 0.3, 0.5, 1.0, 3.0, 5.0, and $10.0 \mu \mathrm{m}$.

\subsection{Aerosol counter of submicron particles 4705 (AeroNanoTech; Russia)}

This portable aerosol counter of submicron particles is intended for measuring the concentration of particles and their size 
distribution in the submicronic range. Five particle channels $(1,2,3,5$, and $10 \mu \mathrm{m})$ were used in our experiment.

\section{Tests}

\section{Integrity of HEPA filters (Test 1)}

The integrity of the filters was checked before the chamber was put into operation, as recommended by GOST R ISO 146443-2007 [7]. The filters were challenged with a control aerosol formulation. Filter surfaces and holding frames were scanned using the SOLAIR 3100 particle counter; alternatively, particle count was performed in the samples of the filtered air collected from the air pipe.

2. Rate and efficiency of air decontamination (Test 2).

Efficiency test of the aerosol sampler designed at the National Research Nuclear University MEPhl

Decontamination tests were conducted in 3 different operating modes. Before the tests, the fans installed in the chamber to set the air in motion and to ensure even distribution of aerosol particles throughout the chamber volume (Fig. 1) and the filtration system were switched on. Upon reaching the air cleanliness of 0-353 particles per $\mathrm{m}^{3}$ (or $0-1$ particle sized 1, 3, 5 , or $10 \mu \mathrm{m}$ as detected by the particle counter), the filters were inactivated, but the fans continued working. Fig. 3 features data obtained starting from this point of the experiment. After the filtration system was switched off, aerosol was generated from a $10 \%$ saccharose solution in distilled water for 5 min by the Comp Air NE-C28 compressor nebulizer (Omron Healthcare Co., Ltd.; Japan) placed inside the chamber. Particles sized 1,3 and $5 \mu \mathrm{m}$ were counted inside the chamber using the counter of submicron particles 4705 . The counter reported an average number of particles per 1 min for 16 minutes in a row. In the first operating mode (precipitation of unstirred aerosol) the fans were turned off, the filtration system inactivated, and aerosol particles counted for 11 minutes. In the second operating mode (precipitation of stirred aerosol) the fans were turned on, filtration switched off, and particles counted for 11 min. Additionally, at this stage of the experiment we introduced the aerosol sampler designed at MEPhl and counted aerosol particles while the device was working. In the third mode (air decontamination from stirred aerosol) the fans were turned off, filtration inactivated, and particles counted for 11 minutes.

\section{Comparing the efficiency of aerosol collection of the two} aerosol samplers (Test 3)

To evaluate the efficiency of polydisperse aerosol collection, we prepared $100 \mathrm{ml}$ of a $10 \%$ saccharose solution in distilled water containing fluorescein sodium salt at a final concentration

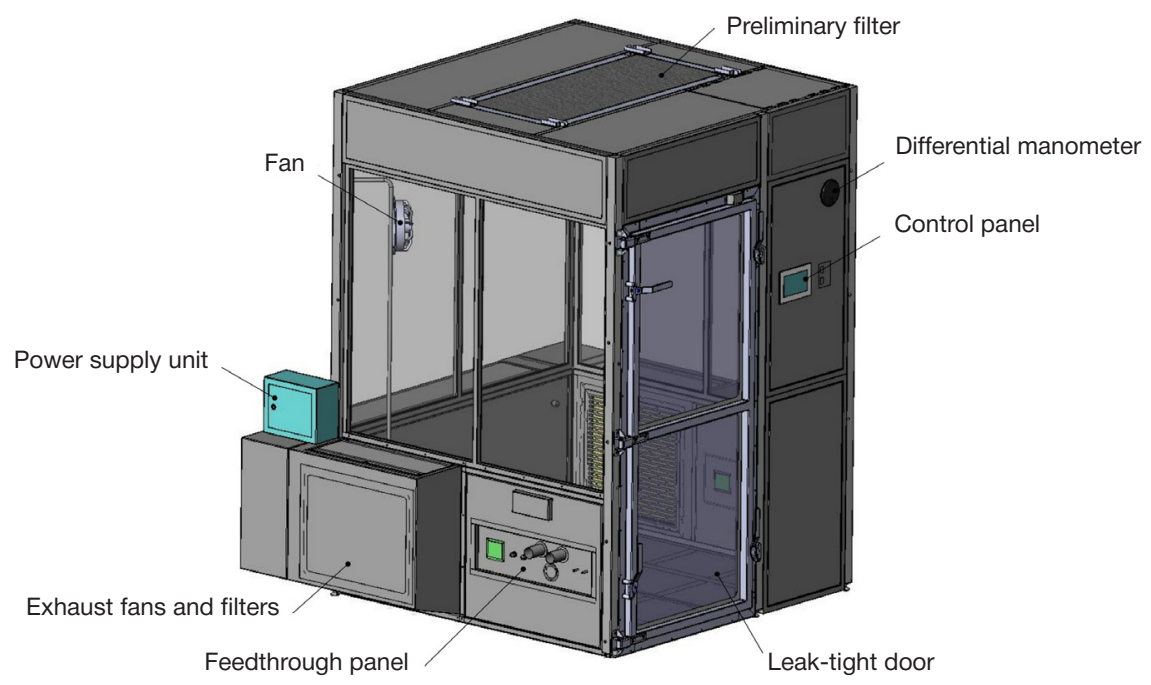

Fig. 1. Laminar-C-1.5 Class III Biosafety Enclosure (380.150.01)

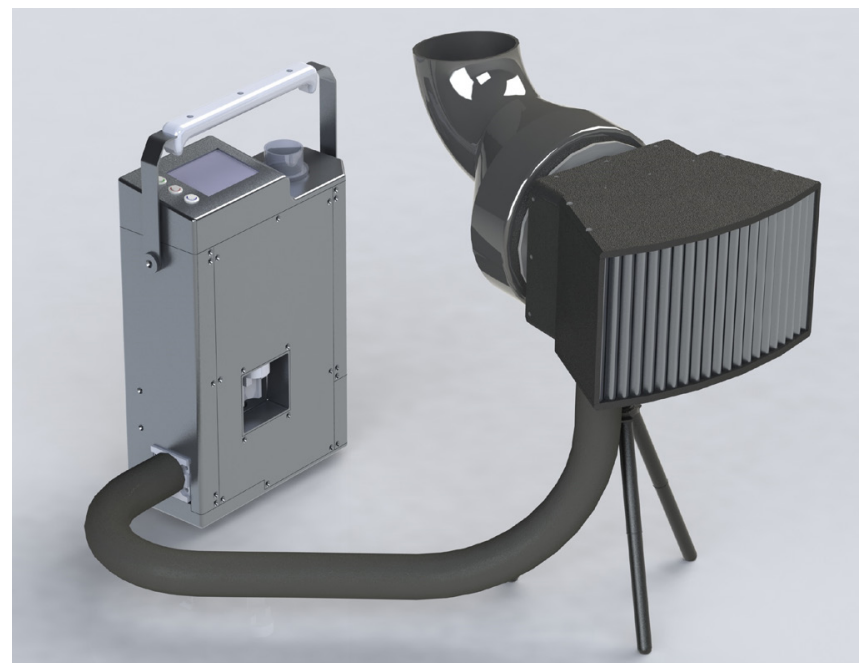

Fig. 2. The aerosol sampling device (National Research Nuclear University MEPhl) 
of $1 \mu \mathrm{M}$. This amount was sufficient to run all the tests we planned. Fluorescence intensity of the collected tracer was measured on the Qubit 3.0 Fluorometer (Invitrogen; USA) in relative fluorescence units at $470 \mathrm{~nm}$ excitation and 510-580 $\mathrm{nm}$ emission wavelengths in $0.6 \mathrm{ml}$ test tubes (SSI; USA) containing carbonate buffer (pH 9.6) (C3041; Sigma; Germany).

All tests were carried out with the fans switched on. Prior to each test, the air inside the chamber was decontaminated. Briefly, the ventilation system was left to work for 15 minutes. Then the cyclone collector was washed automatically with the impactor turned on. After that, control air samples were collected for 6 minutes. For the analysis, we took $270 \mu$ of the sample, mixed them with $30 \mu \mathrm{l} 10 x$ carbonate buffer $(\mathrm{pH} 9.6)$ (C3041; Sigma; Germany) and measured fluorescence intensity. If the measured value exceeded the background fluorescence of empty test tubes, the cyclone collector was washed again. Once the anticipated fluorescence intensity was reached, the ventilation system was turned off.

Aerosol was generated inside the chamber by the compressor nebulizer Comp Air NE-C28 for 5 minutes. Prior to each test the device was washed and wiped dry with a lint-free cloth. Then $4 \mathrm{ml}$ of the saccharose solution containing sodium fluorescein were loaded into the nebulizer. The aerosol sampler was turned on simultaneously with the nebulizer and collected aerosol particles for 6 min, i.e. the sampling process continued for another minute after aerosol generation was terminated. After samples were taken to the lab for the analysis, the cyclone collector was washed as described above.

For each aerosol sampler the tests were done in five replicates.

Table 1. Integrity tests of HEPA filters installed in the chamber

\section{Analysis of workstation performance}

The equipment was commissioned as recommended by GOST R ISO 14644-3-2007. As part of the procedure, the integrity of HEPA filters was evaluated [7].

The conducted tests (Table 1) confirmed that the integrity and efficiency of the installed filters meet the requirements for class $\mathrm{H} 14$ filters.

The rate and efficiency of air decontamination in the chamber is shown in Fig. 3. All graphs demonstrate the contribution of the ventilation system to the dynamics of air decontamination. In figures $A, C$, and $E$ the $Y$-axis is linear, while in $B, D$, and $F$ it is logarithmic. The 3 latter graphs do not include the data obtained in the third operating mode. The number of aerosol particles sized 1 to $5 \mu \mathrm{m}$ decreased to only a few within 3 to 6 minutes of the 11-min-long test when all components of the air purification system were in operation. When the filters were inactivated, decontamination was much slower, especially when the fans were turned off. Most likely, in this operating mode aerosol precipitates on the internal surfaces of the chamber. When the system of air purification is in full operation, it takes only 10 minutes to completely decontaminate the air in the chamber from the generated particles sized 1 to $5 \mu \mathrm{m}$.

The aerosol sampler developed at MEPhI was able to collect 92-99\% of dust (relative to the number of particles measured before collection) within 7 minutes in the ventilated chamber with inactivated air filtration. However, we did not account for the size of the particles present in the air before collection (tens of millions $1 \mu \mathrm{m}$ particles and millions of 3 and $5 \mu \mathrm{m}$ particles) (Table 2).

\begin{tabular}{|c|c|c|c|c|c|}
\hline HEPA filter & $\begin{array}{l}\text { Number of } 0.3 \mu \mathrm{m} \\
\text { particles }\left(N_{c}\right) \text { before air } \\
\text { filtration }\end{array}$ & $\begin{array}{l}\text { Concentration of aerosol } \\
\text { particles per } \mathrm{cm}^{3}\left(C_{c}\right) \text { before } \\
\text { air filtration } \\
\qquad C_{\mathrm{c}}=\frac{N_{\mathrm{c}}}{q_{\mathrm{vs}} \cdot T_{\text {stat }}} \cdot \text { dil }\end{array}$ & $\begin{array}{l}\text { Number of particles } \\
\text { sized } 0.3 \mu \mathrm{m} \text { or larger } \\
\text { after air filtration }\end{array}$ & $\begin{array}{l}\text { The highest detected number } \\
\text { of particles sized } 0.3 \mu \mathrm{m} \text { or } \\
\text { larger exiting the } \\
\text { filter scan }\left(N_{\text {scan }}\right) \\
N_{\text {scan }} \leq C_{\mathrm{c}} \cdot P_{\text {int }} \cdot q_{\mathrm{vs}} \cdot T_{\text {scan }}\end{array}$ & Threshold \\
\hline Inlet filter & 50109 & 1061 & 130 & $\leq 18779$ & Not exceeded \\
\hline $\begin{array}{l}\text { First stage } \\
\text { exhaust filter }\end{array}$ & 91343 & 1935 & 4493 & $\leq 13701$ & Not exceeded \\
\hline $\begin{array}{l}\text { Second stage } \\
\text { exhaust filter }\end{array}$ & 49624 & 1051 & 281 & $\leq 18602$ & Not exceeded \\
\hline$q_{\mathrm{vs}}$ & \multicolumn{5}{|c|}{ Claimed sampling rate of the particle counter $=472 \mathrm{~cm}^{3} / \mathrm{s}$} \\
\hline dil & \multicolumn{5}{|c|}{ Claimed dilution factor $=100$} \\
\hline$T_{\text {stat }}$ & \multicolumn{5}{|c|}{ Recommended time for stationary measurements $=10 \mathrm{~s}$} \\
\hline$P_{\text {int }}$ & \multicolumn{5}{|c|}{ Tolerated local penetration of HEPA filters (GOST R ISO 14644-3-2007) = 0.00025} \\
\hline$T_{\text {scan }}$ & \multicolumn{5}{|c|}{ Sampling time $=150 \mathrm{~s}, 60 \mathrm{~s}$, and $150 \mathrm{~s}$, respectively } \\
\hline
\end{tabular}

Table 2. Rate of dust particle collection by the aerosol sampler (National Research Nuclear University MEPhl)

\begin{tabular}{|c|c|c|c|c|c|c|}
\hline \multirow{2}{*}{$\begin{array}{l}\text { Time elapsed from } \\
\text { the start of the test } \\
\text { (min) }\end{array}$} & \multicolumn{2}{|c|}{$1 \mu \mathrm{m}$ particles } & \multicolumn{2}{|c|}{$3 \mu \mathrm{m}$ particles } & \multicolumn{2}{|c|}{$5 \mu \mathrm{m}$ particles } \\
\hline & 56829268 & $100 \%$ & 6700900 & $100 \%$ & 1289540 & $100 \%$ \\
\hline 7 & 41036585 & $72 \%$ & 3322200 & $50 \%$ & 555680 & $43 \%$ \\
\hline 8 & 21097561 & $37 \%$ & 1062200 & $16 \%$ & 160966 & $12 \%$ \\
\hline 10 & 11707317 & $21 \%$ & 497200 & $7 \%$ & 51038 & $4 \%$ \\
\hline 11 & 6951220 & $12 \%$ & 265550 & $4 \%$ & 17032.8 & $1 \%$ \\
\hline 12 & 4512195 & $8 \%$ & 172890 & $3 \%$ & 6402.4 & $0.5 \%$ \\
\hline
\end{tabular}




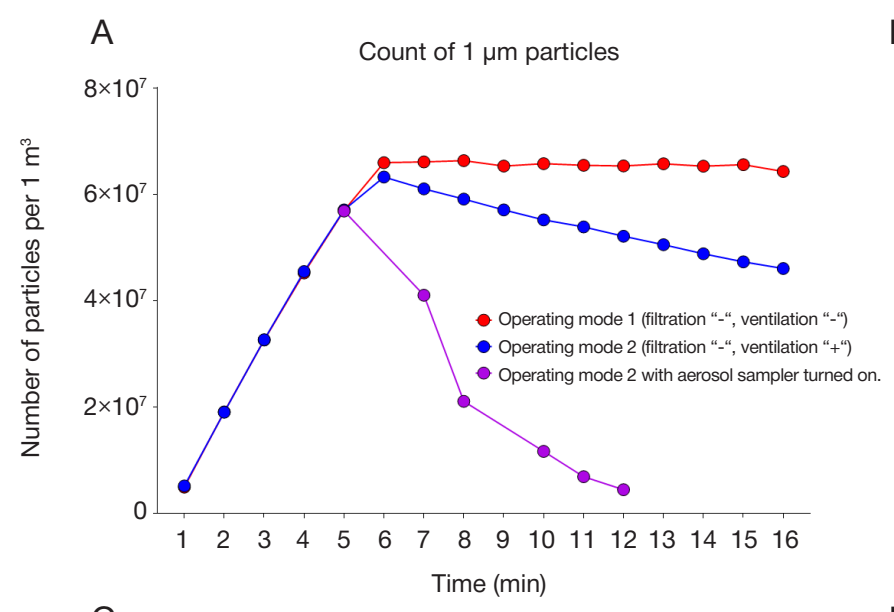

C

Count of $3 \mu \mathrm{m}$ particles

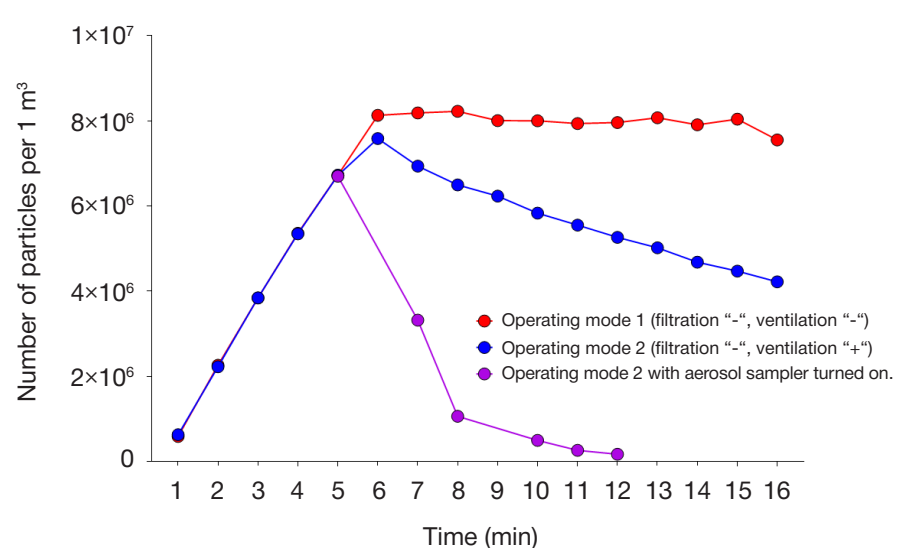

E

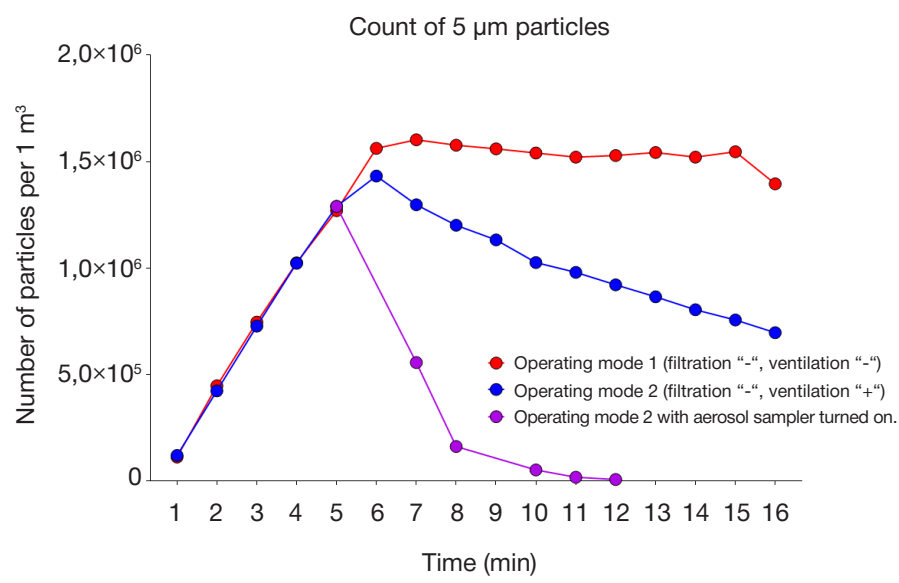

$\mathrm{B}$

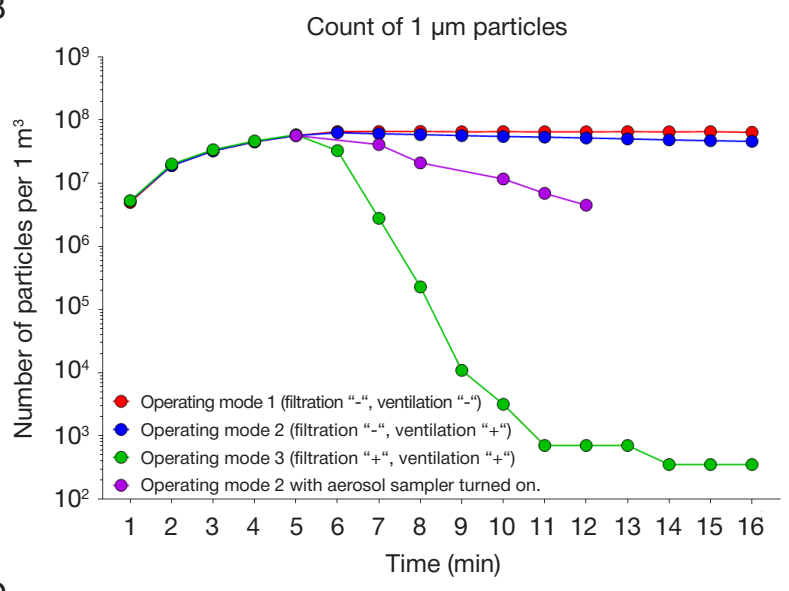

D

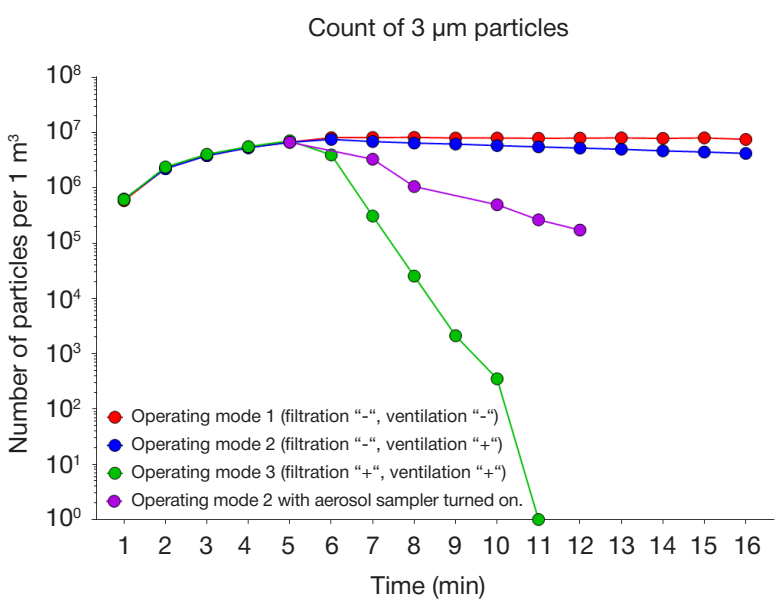

$\mathrm{F}$

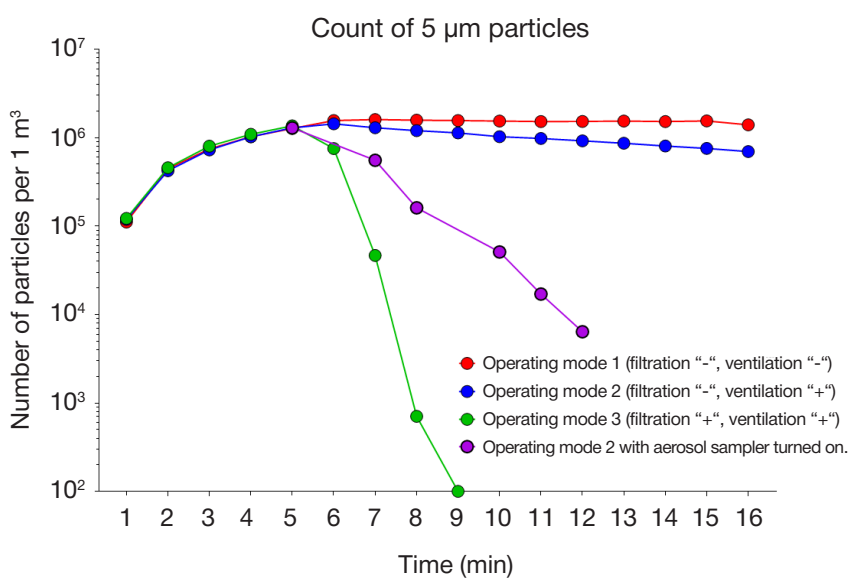

Fig. 3. Dynamics of air decontamination from 1 to $10 \mu \mathrm{m}$ particles $(\mathbf{A}-\mathbf{F})$ in the Laminar-C-1.5 Class III Biosafety Enclosure after 5 minutes of aerosol generation in different operating modes

Table 3 demonstrates the efficiency of polydisperse aerosol collection evaluated from the fluorescence intensity of the tracer. Fluorescence expressed in relative fluorescence units was normalized to the volume of the released liquid sample for each device. The prototype of the aerosol sampler developed at the National Research Nuclear University MEPhl has an average rate of collection similar to that of SASS; based on the results of 5 measurements, the difference is insignificant ( $p>0.05$; Student's T-test applied). For each of the compared aerosol samplers 4 washes in the ventilated environment were enough to remove the fluorescent tracer and reach the level of background fluorescence.

\section{Discussion of the results}

There are a few factors complicating the study of properties exhibited by biopathogens in ambient air. First, bioaerosols must be generated in enclosed laboratory spaces to prevent damage to the environment and people. Seconds, such enclosures must have an inbuilt system for rapid and efficient air decontamination and disinfection after the experiment. Third, they must satisfy the strict sanitation and safety requirements set by state agencies. Finally, our high-tech age demands that such chambers should be made from cutting-edge environment-friendly materials and equipped with sensors to 
Table 3. Efficiency of polydisperse aerosol collection

\begin{tabular}{|c|c|c|c|}
\hline Aerosol sampler & Average sample volume, $\mathrm{ml}$ & Average RFU/ml considering error of measurement & Relative to SASS, $\%$ \\
\hline MEPhl & 7.5 & $1441 \pm 98$ & 97.7 \\
\hline SASS & 4.5 & $1475 \pm 122$ & 100 \\
\hline
\end{tabular}

monitor pressure, temperature, air flow rate, air cleanliness, and other parameters inside the chamber and have electronic panels for control and data input [8-10].

All of these factors have to be accounted for in the design of the end product. Given that it is not intended for mass production, the final price can be really formidable.

In Russia, such workstations are available in the shared facilities of big research institutions. A good example is an enclosure for static and dynamic aerosol measurements designed at the State Research Institute for Biological Instrumentation to test the technical parameters of biosafety systems in the controlled environment at temperatures ranging from - 20 to $+40{ }^{\circ} \mathrm{C}$ and relative humidity of 30 to $95 \%$ [11]. This huge enclosure (static chamber sizes are 8 and $26 \mathrm{~m}^{3}$ ) is a perfect space to experiment with pathogenic aerosols and airborne microorganisms. Sadly, for technical reasons the Institute cannot work with pathogens included in the hazard groups 3 and 4 which seriously limits the range of tested bioaerosols to their simulators. Although a series of minor experiments can be conveniently conducted here, the situation does not favor long-term extensive research, which is very unfortunate given construction costs.

Class III biosafety cabinets are cheaper and, therefore, more available. They protect the operator and the environment from contamination by hazardous aerosols resulting from manipulations with pathogenic agents and also protect the agents inside the chamber from external contamination. Cabinets are intended for one or two operators and their internal working space is quite small $\left(>1 \mathrm{~m}^{3}\right)$.

The experimental workstation described and successfully tested in this study is a trade-off between the two. This Laminar-C-1.5 Class III Biosafety Enclosure (380.150.01) was designed to test the devices for testing and analyzing model pathogenic bioaerosols. Class H14 HEPA filters installed in the chamber capture over $99.995 \%$ of generated particles sized $>0.3 \mu \mathrm{m}[12]$. The primary application of these filters is air decontamination from radioactive particulate matter with $99.97 \%$ efficiency. They have a few drawbacks. The majority of (but not all) bacteria are from 0.4 (Proteus mirabilis) to 10 $\mu \mathrm{m}$ (Clostridium perfringens) in size; pathogenic fungi vary in size from 1 (Pneumocystis jirovecii) to $20 \mu \mathrm{m}$ (Fusarium sp.). Viruses fall into the range from 0.02 (Rhinovirus) to 0.3
(Mumps virus) $\mu \mathrm{m}$ [13]. In addition, for some pathogens the infective dose is really tiny, such as $<10$ bacterial cells for Coxiella burnetii that causes $Q$ fever. These 10 cells may well be part of those $0.005 \%$ of the particles that are not retained by the filter in the experiment where the number of the sprayed bacteria is $10^{7} \mathrm{CFU}$ or higher [14]. Studies of HEPA filters involving the MS2 phage have shown that filtration efficiency is directly dependent on the air flow rate [15]. Thus, the choice of filters is largely determined by the task set for the researcher. Our Laminar-C-1.5 Class III Biosafety Enclosure is equipped with two consecutive exhaust HEPA filters (the calculated particle penetration value is $3 \times 10^{-9} \%$ ) and is capable of maintaining the optimal air flow rate, ensuring sufficient protection in the experiments involving high concentrations of biopathogens (up to $10^{6}-10^{7} \mathrm{CFU} / \mathrm{m}^{3}$ ). The conducted tests (Table 1) prove that the filters satisfy the state requirements for integrity and efficiency and that the chamber can be used for the majority of standard tasks.

Tests of the rate and efficiency of air decontamination from 1,3 and $5 \mu \mathrm{m}$ particles have shown that aerosol concentration remains more or less stable for quite a long time (11 minutes) if the systems of filtration and ventilation are turned off. When the fans inducing air circulation in the chamber are turned off, the concentration of particles of all three sizes slightly decreases within the same time interval. The system of air decontamination has demonstrated high rate and efficiency by removing all particulate admixtures from the air in 3 to 6 minutes depending on the size and number of the particles generated in the chamber. In test 3 some parameters of the aerosol sampler developed at the National Research Nuclear University MEPhl were compared to those of its foreign counterpart.

\section{CONCLUSION}

Laminar-C-1.5 Class III Biosafety Enclosure (380.150.01) is a high-quality workstation for aerosol tests that can be installed inside a lab. The volume of the work chamber is $4.275 \mathrm{~m}^{3}$, which is sufficient for the first- and second-level tests involving the majority of biopathogens. The workstation can be used to test aerosol samplers and study bioaerosol behavior at various concentrations in static and dynamic modes.

\section{References}

1. Lacey J, Dutkiewicz J. Bioaerosols and Occupational Lung Desease. J Aerosol Sci. 1994; 25 (8): 1371-404.

2. Li Y, Leung GM, Tang JW, et al. Role of Ventilation in Airborne Transmission of Infectious Agents in the Built Environment - a Multidisciplinary Systematic Review. Indoor Air. 2007; (17): 2-18.

3. Tu AT. Aum Shinrikyo's Chemical and Biological Weapons: More Than Sarin. Forensic Sci Rev. 2014; 26 (2): 115-20.

4. Schep LJ, Temple WA, Butt GA, Beasley MD. Ricin as a weapon of mass terror--separating fact from fiction. Environ Int. 2009; 35 (8): 1267-71.

5. SP 1.3.1285-2003. Bezopasnost' raboty s mikroorganizmami I-II grupp patogennosti (opasnosti). Minjust RF. Reg. nom. 4545 (15 maja 2003).

6. GOSTR EN 12469-2010. Biotehnologija. Tehnicheskie trebovanija

k boksam mikrobiologicheskoj bezopasnosti. Rosstandart. Reg. nom. 1144-st (29 dekabrja 2010).

7. GOST R ISO 14644-3-2007. Chistye pomeshhenija i svjazannye s nimi kontroliruemye sredy. Chast' 3 . Metody ispytanij. Rosstandart. Reg. nom. 616-st (27 dekabrja 2007).

8. Bezopasnost' raboty s mikroorganizmami I-II grupp patogennosti (opasnosti): Sanitarno-jepidemiologicheskie pravila SP 1.3.311813. M.: Federal'nyj centr gigieny ijepidemiologii Rospotrebnadzora; 2014. 195 s.

9. Bezopasnost' raboty $\mathrm{S}$ mikroorganizmami III-IV grupp patogennosti (opasnosti) i vozbuditeljami parazitarnyh boleznej: Sanitarno-jepidemiologicheskie pravila SP 1.3.2322-08 (s izmenenijami na 29 ijunja 2011 g). Dostupno po ssylke: http:// docs.cntd.ru/document/902091086 
10. Bezopasnost' raboty $\mathrm{s}$ mikroorganizmami III-IV grupp patogennosti (opasnosti) i vozbuditeljami parazitarnyh boleznej. Dopolnenija i izmenenija N 1 k SP 1.3.2322-08. Sanitarnojepidemiologicheskie pravila SP 1.3.2518-09. M.: Federal'nyj centr gigieny i jepidemiologii Rospotrebnadzora; 2009. 8 s.

11. Nauchno-tehnologicheskaja infrastruktura Rossijskoj Federacii. Centry kollektivnogo pol'zovanija nauchnym oborudovaniem i unikal'nye nauchnye ustanovki. Dostupno po ssylke: http://ckprf.ru/usu/73550/

12. lamsys.ru [internet]. ZAO "Laminarnye sistemy" Dostupno po ssylke: http://www.lamsys.ru/nera.php

\section{Литература}

1. Lacey J, Dutkiewicz J. Bioaerosols and Occupational Lung Desease. J Aerosol Sci. 1994; 25 (8): 1371-404.

2. Li Y, Leung GM, Tang JW, et al. Role of Ventilation in Airborne Transmission of Infectious Agents in the Built Environment - a Multidisciplinary Systematic Review. Indoor Air. 2007; (17): 2-18.

3. Tu AT. Aum Shinrikyo's Chemical and Biological Weapons: More Than Sarin. Forensic Sci Rev. 2014; 26 (2): 115-20.

4. Schep LJ, Temple WA, Butt GA, Beasley MD. Ricin as a weapon of mass terror--separating fact from fiction. Environ Int. 2009; 35 (8): 1267-71.

5. СП 1.3.1285-2003. Безопасность работы с микроорганизмами I-II групп патогенности (опасности). Минюст РФ. Рег. ном. 4545 (15 мая 2003).

6. ГОСТ Р ЕН 12469-2010. Биотехнология. Технические требования к боксам микробиологической безопасности. Росстандарт. Рег. ном. 1144-ст (29 декабря 2010).

7. ГОСТ Р ИСО 14644-3-2007. Чистые помещения и связанные с ними контролируемые среды. Часть 3. Методы испытаний. Росстандарт. Рег. ном. 616-ст (27 декабря 2007).

8. Безопасность работы с микроорганизмами І-ІІ групп патогенности (опасности): Санитарно-эпидемиологические правила СП 1.3.3118-13. М.: Федеральный центр гигиены и эпидемиологии Роспотребнадзора; 2014. 195 с.

9. Безопасность работы с микроорганизмами III-IV групп патогенности (опасности) и возбудителями паразитарных болезней: Санитарно-эпидемиологические правила СП
13. Kowalski W. Hospital Airborne Infection Control. CRC Press. 2012; p. 42-48.

14. EJ van Schaik, C. Chen, K. Mertens, MM Weber, JE Samuel. Molecular pathogenesis of the obligate intracellular bacterium Coxiella burnetii. Nat Rev Microbiol. 2013; 11 (8): 561-73.

15. Heimbuch BK, Hodge JE, Wander JD. Viral Penetration of High Efficiency Particulate Air (HEPA) Filters. 5th ASM Biodefense and Emerging Diseases Research Meeting; 200727 Feb-2 Mar; Washington DC. Available from: https://www.researchgate.net/ publication/235151297_Viral_Penetration_of_High_Efficiency Particulate_Air_HEPA_Filters

1.3.2322-08 (с изменениями на 29 июня 2011 года). Доступно по ссылке: http://docs.cntd.ru/document/902091086

10. Безопасность работы с микроорганизмами III-IV групп патогенности (опасности) и возбудителями паразитарных болезней. Дополнения и изменения N 1 к СП 1.3.2322-08. Санитарно-эпидемиологические правила СП 1.3.251809. М.: Федеральный центр гигиены и эпидемиологии Роспотребнадзора; 2009. 8 с.

11. Научно-технологическая инфраструктура Российской Федерации. Центры коллективного пользования научным оборудованием и уникальные научные установки. Доступно по ссылке: http://ckp-rf.ru/usu/73550/

12. lamsys.ru [internet]. ЗАО "Ламинарные системы" Доступно по ссылке: http://www.lamsys.ru/nera.php

13. Kowalski W. Hospital Airborne Infection Control. CRC Press. 2012; p. 42-48.

14. EJ van Schaik, C. Chen, K. Mertens, MM Weber, JE Samuel. Molecular pathogenesis of the obligate intracellular bacterium Coxiella burnetii. Nat Rev Microbiol. 2013; 11 (8): 561-73.

15. Heimbuch BK, Hodge JE, Wander JD. Viral Penetration of High Efficiency Particulate Air (HEPA) Filters. 5th ASM Biodefense and Emerging Diseases Research Meeting; 200727 Feb - 2 Mar; Washington DC. Available from: https://www.researchgate.net/ publication/235151297_Viral_Penetration_of_High_Efficiency_ Particulate_Air_HEPA_Filters 